\title{
Quercetin suppresses inflammation by reducing ERK1/2 phosphorylation and NF kappa B activation in Leptin-induced Human Umbilical Vein Endothelial Cells (HUVECs)
}

\author{
Mochamad Rasjad Indra ${ }^{1 *}$, Satuman Karyono ${ }^{1}$, Retty Ratnawati ${ }^{1}$ and Safarina G Malik²
}

\begin{abstract}
Background: High concentrations of plasma leptin and the release of pro-inflammatory cytokines in leptin-resistance in obesity have been reported to trigger endothelial dysfunction. The objective of this study was to elucidate the role of quercetin in modulating leptin-induced inflammation as assessed by the levels of Ob-Ra expression, ERK1/2 phosphorylation, NF-kappa B activation and TNF-alpha secretion in umbilical vein endothelial cells (HUVECs) in vitro.

Findings: HUVECs were exposed to either control levels $(0 \mathrm{ng} / \mathrm{ml})$ or $500 \mathrm{ng} / \mathrm{mL}$ leptin $(\mathrm{L})$ for 48 hours, followed by control or 125 uM quercetin (Q) for another 6 h. The experimental groups were as follows: L0Q0, L0Q125, L500Q0, L500Q125. The presence of the short chain leptin receptor isoform Ob-Ra in HUVECs was determined by Western blot and immunocytochemistry analyses. Ob-Ra expression, ERK1/2 phosphorylation, NF-kappa B activation and TNF-alpha secretion were quantified by ELISA, and NF-kappa B activationby immunofluorescence staining. Our results showed that Ob-Ra expression, ERK1/2 phosphorylation and NF-kappa B activation increased significantly after $500 \mathrm{ng} / \mathrm{mL}$ leptin exposure $(1.8 x, 1.5 x, 6.2 x$ for Ob-Ra, ERK1/2 and NF-kappa B, respectively), but were reduced by addition of $125 \mathrm{uM}$ quercetin $(0.7 x, 0.3 x$ and $0.4 x$ for Ob-Ra, ERK1/2 and NF-kappa B, respectively), and that quercetin could also partially suppress leptin-induced TNF-alpha secretion (3.8x) by $0.8 \mathrm{x}$.
\end{abstract}

Conclusion: Exposure of HUVECs to leptin up-regulated Ob-Ra expression and elevated ERK1/2 phosphorylation and NFkB activation, and increased TNF-alpha secretion. These effects strongly suppressed by quercetin, with the exception of TNF-alpha which was partially suppressed. The findings might be of clinical significance, as endothelial dysfunction that could lead to cardiovascular disease is preventable, and quercetin is a natural compound found in various plants and fruits.

Keywords: Leptin, Quercetin, Ob-Ra, ERK1/2, NFKB, TNFa, HUVECs

\section{Findings}

Obesity has become a global health problem, with the prevalence of overweight and obesity reaching critical levels throughout the world, including Indonesia. A national survey in 2007 in 12 Indonesian provinces showed that $18.8 \%$ of the population older than 15 years old are obese [1]. Obesity is a major risk factor for cardiovascular

\footnotetext{
* Correspondence: rasjadindra@yahoo.com

${ }^{1}$ Department of Physiology, Faculty of Medicine, Brawijaya University,

Jl. Veteran, Malang 65145, East Java, Indonesia

Full list of author information is available at the end of the article
}

disease, hypertension, dyslipidemia and diabetes mellitus, all of which reduce both the quality of life and life expectancy. Obesity is associated with excessive adipose tissue accumulation due to excessive energy intake and insufficient energy expenditure [2], and is characterized by the alteration of leptin levels, a cytokine produced by adipocytes and one of the regulators of energy metabolism. Studies have shown that most obese patients are leptin resistant, and high leptin levels were observed in these individuals [3]. An association between leptin and increased cardiovascular risk has been reported [4], and is associated with increased levels of inflammatory factors exhibiting

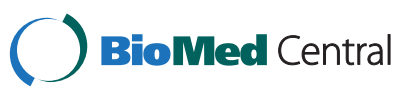


pro-atherogenic effects [5-7]. Obesity has also been considered as a state of low-grade inflammation [8]; previous research has shown that atherosclerosis is the result of chronic inflammation, and early atherosclerosis formation is induced by pro-inflammatory cytokines and other proteins produced by inflammatory cells $[9,10]$.

In obesity-related high plasma leptin conditions, inflammation occurs when signal transduction pathways are activated, such as activation of $\mathrm{NF \kappa B}$, by the binding of leptin to its receptor (Ob-R), and subsequent release of the inflammation factors, for instance tumour necrosis factor alpha (TNF $\alpha)$ [11]. Our preliminary results revealed that $500 \mathrm{ng} / \mathrm{ml}$ leptin decreases cell proliferation and increases TNF $\alpha$, monocyte chemoattractant protein1 (MCP-1), and intracellular $\mathrm{Ca}^{2+}$ levels in human umbilical vein endothelial cells (HUVECs) [12].

Quercetin, a flavonoid compound found in plants and fruits, has been reported to have anti-inflammatory effects [13], which are mediated through the inhibition of pro-inflammatory cytokines [14]. The aim of this study was to investigate the effect of quercetin in modulating the expression of Ob- $\mathrm{Ra}$, phosphorylation of ERK1/2, activation of NFKB and secretion of TNF $\alpha$ in leptin-induced human umbilical vein endothelial cells (HUVECs) in vitro.

\section{Methods \\ Samples}

Human umbilical vein endothelial cells (HUVECs) were obtained from umbilical cords of patients that have undergone cesarean section in Dr. Syaiful Anwar Hospital, Malang, after obtaining informed consent. This research was approved by the institutional research ethical committee from the Faculty of Medicine, Brawijaya University, Malang.

\section{Cell culture and treatment}

HUVECs were isolated and cultured as described previously $[15,16]$. Briefly, HUVECs were cultured in M199 medium (Sigma-Aldrich, USA) supplemented with $10 \%$ fetal calf serum (Biochrom, Germany), $0.0292 \mathrm{~g} /$ $\mathrm{mL}$ L-glutamine (Gibco, USA), $50 \mathrm{U} / \mathrm{mL}$ penicillin (Gibco, USA), and $50 \mathrm{mg} / \mathrm{mL}$ streptomycin (Gibco, USA), at $37^{\circ} \mathrm{C}$ in a $5 \% \mathrm{CO} 2$ incubator. Human recombinant leptin (500 ng/mL; Sigma-Aldrich, USA) dissolved in dimethyl sulfoxide/DMSO (MPBio, USA) was added to HUVECs and incubated for 48 hours. Quercetin (125 $\mu \mathrm{M}$; Sigma-Aldrich, USA) dissolved in methylcellulose (MPBio, USA), was added to leptinexposed HUVECS for 6 hours. HUVECs that were not exposed to leptin were treated with $0 \mu \mathrm{M}$ and $125 \mu \mathrm{M}$ quercetin for 6 hours. Quercetin concentration of 125 $\mu \mathrm{M}$ was reported to have marginal cell toxicity [17].
The experimental groups were: L0Q0 without leptin and quercetin (control, with DMSO and methylcellulose only); L0Q125 without leptin but with $125 \mu \mathrm{M}$ quercetin; L500Q0 with $500 \mathrm{ng} / \mathrm{mL}$ leptin but without quercetin; L500Q125 with $500 \mathrm{ng} / \mathrm{mL}$ leptin and $125 \mu \mathrm{M}$ quercetin. The experiments were repeated 5 times for each group.

\section{Western blot analysis}

Proteins were extracted from HUVECs by using mammalian protein extraction reagent (Pierce, IL). Protein concentrations were determined using Coomassie protein reagent (Bio-Rad, CA). Thirty micrograms of total protein was loaded per lane and separated by $7.5 \%$ sodium dodecyl sulfate-Tris-glycine polyacrylamide gel electrophoresis. Proteins were transferred to nitrocellulose membranes and blocked overnight in Tris-buffered saline (TBS) containing 0.1\% Tween and $5 \%$ nonfat dry milk. Membranes were probed with rabbit polyclonal antibody directed against either human short leptin receptor (ObRa) or human phosphorylated ERK1/2 or human p65 NFkB antibodies (1:1000; Cell Signaling, MA), or mouse antihuman $\beta$-actin monoclonal antibody (1:1.000; Santa Cruz Biotech, USA), then were detected using Biotinconjugated goat anti-rabbit IgG (Santa Cruz Biotech, USA). Visualization was done after incubation with streptavidin-alkaline phosphatase conjugate (Invitrogen, USA), by employing colorimetric detection using nitroblue tetrazolium/5-bromo-4-chloro-3-indolylphosphate reagent (Roche, IN).

\section{Ob-Ra Immunocytochemistry}

HUVECs were fixed with methanol in glass slides, then gently rinsed with phosphate buffer solution (PBS). Normal human serum (1:10 dilution) (MPBio, USA) was applied and incubated for $20-30$ minutes at $37^{\circ} \mathrm{C}$. Rabbit anti-human Ob-Ra antibody (1:100) (Santa Cruz Biotech, USA) was applied and the specimens were incubated overnight at $4^{\circ} \mathrm{C}$. Labelled anti rabbit IgG-SA-HRP (KPL, USA) was applied for 60 minutes, then substratechromogen solution 3,3'-diaminobenzidine was added, and the specimens were incubated for 10 minutes. Hematoxylin counterstaining was performed to stain the nucleus. The slides were then covered with cover slips.

\section{Ezyme linked immunosorbent assay}

Cell lysate were obtained from harvested HUVECs, then ELISA was performed to quantify the level of Ob-Ra (BioSource International, USA), total phosphorylated ERK1/2 (Assay Designs, USA), and p50/ p 65 NFkB (Imgenex, USA).

ELISA for secreted TNF $\alpha$ (Bender MedSystem, Austria) was conducted using the supernatant of HUVECs culture. 


\section{NFKB Immunofluorescence}

Sub-confluent HUVECs grown on cover slips were fixed with methanol at room temperature for 10 minutes, labeled with $10 \mu \mathrm{g} / \mathrm{mL}$ antihuman p50/p65 NFkB antibody (Thermo Scientific, USA) for 1 hour, washed 3 times with PBS, then incubated with $8 \mu \mathrm{g} / \mathrm{mL}$ FITC-labeled goat anti-rabbit IgG (Santa Cruz Biotechnology Inc, USA) for 1 hour. Bound antibody was detected using Fluo view 1000 confocal microscope (Olympus, Japan) equipped for epiluminescence.

\section{Statistical analyses}

Results were the average of at least five repeats. Differences between groups were determined by ANOVA, followed by Tukey's test (SPSS vs. 17). All data were shown as means $\pm \mathrm{SD}$, and $p<0.05$ was considered statistically significant.

\section{Results}

\section{Ob-Ra was expressed in HUVECs}

The short isoform of leptin receptor (Ob-Ra) was expressed in HUVECs, as demonstrated by Western blot analysis shown in Figure 1A. After leptin induction the expression of Ob-Ra was increased almost two folds as compared to control (band intensities are $1488 \pm 355.4$ vs. $2586 \pm 380.8$, without and with leptin exposure, $p=0.001)$. Immunocytochemistry staining confirmed the increased expression of $\mathrm{Ob}-\mathrm{Ra}$ in leptin-induced HUVECs (Figure 1B).

\section{Quercetin down-regulated leptin receptor expression}

The short isoform of leptin receptor (Ob-Ra) expression was significantly increased $1.8 \mathrm{x}$ after 48 hours leptin exposure $(500 \mathrm{ng} / \mathrm{ml})(9966 \pm 194.0$ vs. $18116 \pm$ $1823 \mathrm{ng} / \mathrm{mL}$, L0Q0 vs. L500Q0, $p=10^{-4}$ ). Quercetin (125 $\mu \mathrm{M})$ down-regulated the leptin-induced Ob-Ra expression by $0.7 \mathrm{x}(13449 \pm 235.3$ vs. $18116 \pm 1823 \mathrm{ng} /$ $\mathrm{mL}$, L500Q125 vs. L500Q0, $p=0.028)$. Quercetin alone (L0Q125) increased leptin receptor expression $(13660 \pm 1452$ vs. $9966 \pm 194.0 \mathrm{ng} / \mathrm{mL}$, L0Q125 vs. LOQ0, $p=0.020$ ) (Figure 2).

\section{Quercetin reduced leptin-induced ERK1/2 phosphorylation}

Quantitative measurement by ELISA revealed a $1.5 \mathrm{x}$ higher total phosphorylated ERK1/2 level in leptininduced HUVECs $(85.00 \pm 10.44$ vs. $129.3 \pm 22.55 \mathrm{ng} /$ $\mathrm{mL}, \mathrm{L0Q} 0$ vs. L500Q0, $p=0.012$ ). Addition of $125 \mu \mathrm{M}$ quercetin (L500Q125) reduced ERK1/2 phosphorylation in leptin-induced HUVECs by $0.3 \mathrm{x}$ (40.00 \pm 1.73 vs. $129.3 \pm 22.55 \mathrm{ng} / \mathrm{mL}$, L500Q125 vs. L500Q0, $p=10^{-4}$ ). We observed that quercetin alone also reduced ERK1/2 total phosphorylation $(43.33 \pm 4.93$ vs. $85.00 \pm 10.44 \mathrm{ng} /$ $\mathrm{mL}, \mathrm{L} 0 \mathrm{Q} 125$ vs. L0Q0, $p=0.016$ ) (Figure 3).

\section{Quercetin inhibited leptin-induced NFkB activation}

FITC immunolabeling was used to determine the NFKB activation. As shown in Figure 4A signal density was increased after HUVECs was exposed to $500 \mathrm{ng} / \mathrm{mL}$ leptin as compared to control. Quercetin alone did not
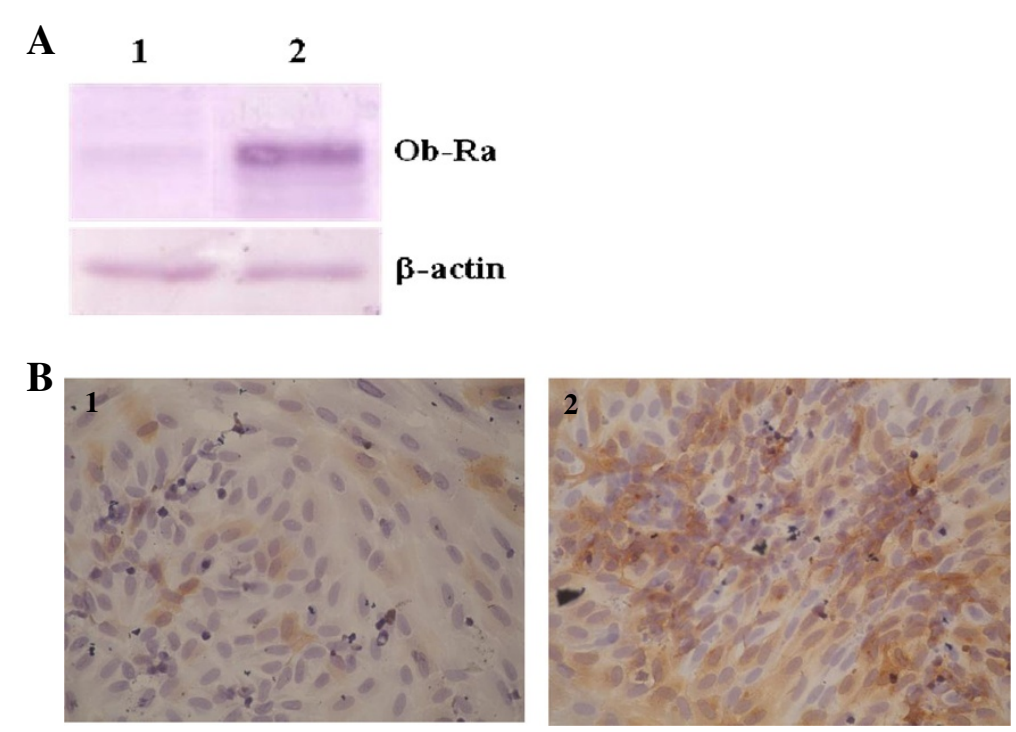

Figure 1 Ob-Ra was expressed in HUVECs. (A) Western blot analysis of Ob-Ra in HUVECs showed that exposure of $500 \mathrm{ng} / \mathrm{mL}$ leptin for $48 \mathrm{~h}$ increased Ob-Ra expression (without (lane 1) and with (lane 2) leptin exposure). $\beta$-actin expression in leptin-induced HUVECs was similar with control (without leptin induction). (B) Confirmation of increased Ob-Ra expression after leptin exposure by immunocytochemistry using specific antibody against Ob-Ra (without (panel 1) and with (panel 2) leptin exposure). 


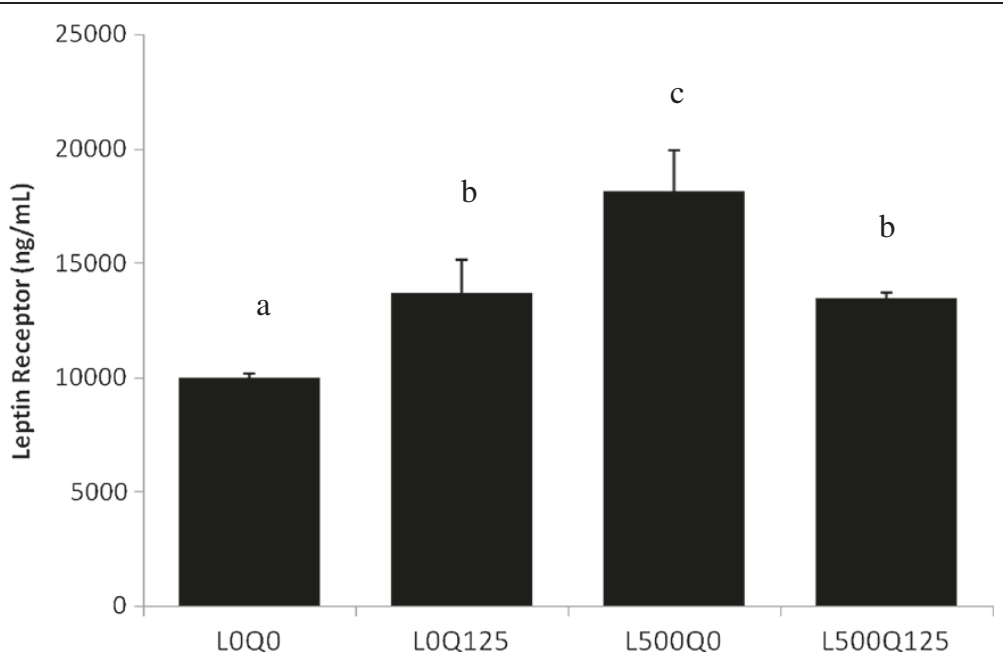

Figure 2 Quercetin down-regulates leptin receptor expression. Ob-Ra expression measured by ELISA was increased after $500 \mathrm{ng} / \mathrm{mL}$ leptin exposure, and $125 \mu \mathrm{M}$ quercetin addition was able to decrease the expression of Ob-Ra in leptin-induced HUVECs. LOQO control HUVECs without leptin and quercetin; L0Q125 without leptin, but with $125 \mu \mathrm{M}$ quercetin; L500Q0 with 500 ng/mL leptin, but without quercetin; L500Q125 with $500 \mathrm{ng} / \mathrm{mL}$ leptin and $125 \mu \mathrm{M}$ quercetin. Means without a common letter differ, at least $p<0.05$.

induce NFkB activation. However, quercetin addition in leptin-induced HUVECs reduced the density of NFKB. This phenomenon was confirmed by Western blot analysis (Figure 4B). A further confirmation by ELISA showed a significant $6.2 \mathrm{x}$ increased of NFkB activation in leptin-induced HUVECs when compared to control $(111.6 \pm 24.35$ vs. $692.4 \pm 9.849 \mathrm{ng} / \mathrm{mL}$, L0Q0 vs. L500Q0, $p=10^{-5}$ ). After quercetin addition, NFKB activation was significantly reduced by $0.4 \mathrm{x}(304.4 \pm$ 53.33 vs. $692.4 \pm 9.849 \mathrm{ng} / \mathrm{ml}$, L500Q125 vs. L500Q0,

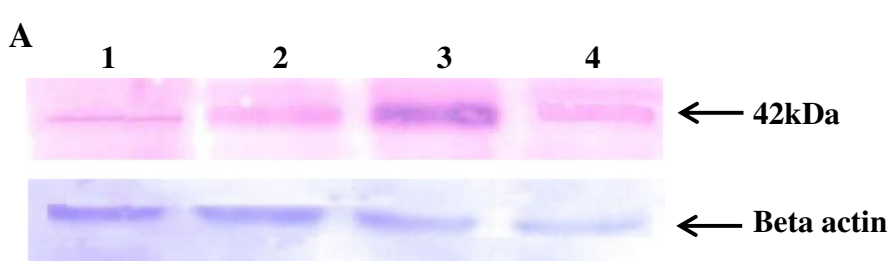

B

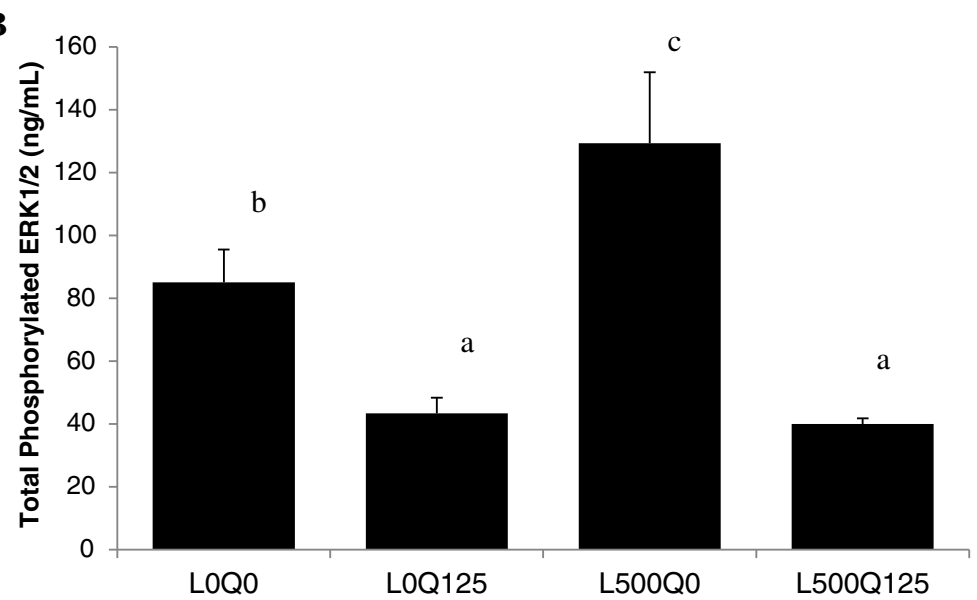

Figure 3 Quercetin reduced leptin-induced ERK1/2 phosphorylation. (A) Western blot analysis of phosphorylated ERK1/2 in HUVECS showed that $500 \mathrm{ng} / \mathrm{mL}$ leptin exposure for $48 \mathrm{~h}$ increased ERK1/2 phosphorylation (without (lane 1) and with (lane 3) leptin exposure). Quercetin alone did not show any effect (lane 2), nevertheless in leptin-induced HUVECs, ERK1/2 phosphorylation was reduced (lane 4). (B) Total phosphorylated ERK1/2 level measured by ELISA was reduced after quercetin treatment on leptin-induced HUVECs. LOQO control HUVECs without leptin and quercetin; L0Q125 without leptin, but with $125 \mu$ M quercetin; L500Q0 with $500 \mathrm{ng} / \mathrm{mL}$ leptin, but without quercetin; L500Q125 with $500 \mathrm{ng} / \mathrm{mL}$ leptin and $125 \mu \mathrm{M}$ quercetin. Means without a common letter differ, at least $p<0.05$. 
A
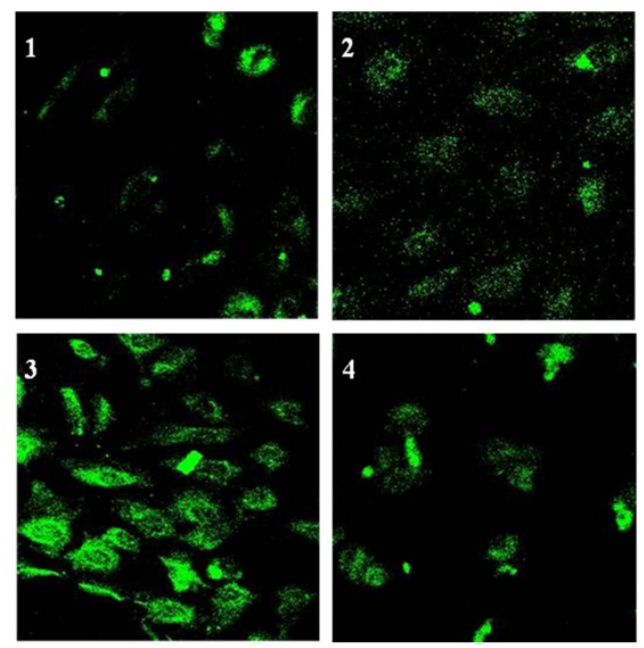

$\mathbf{B}$

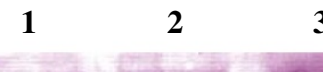

3

4
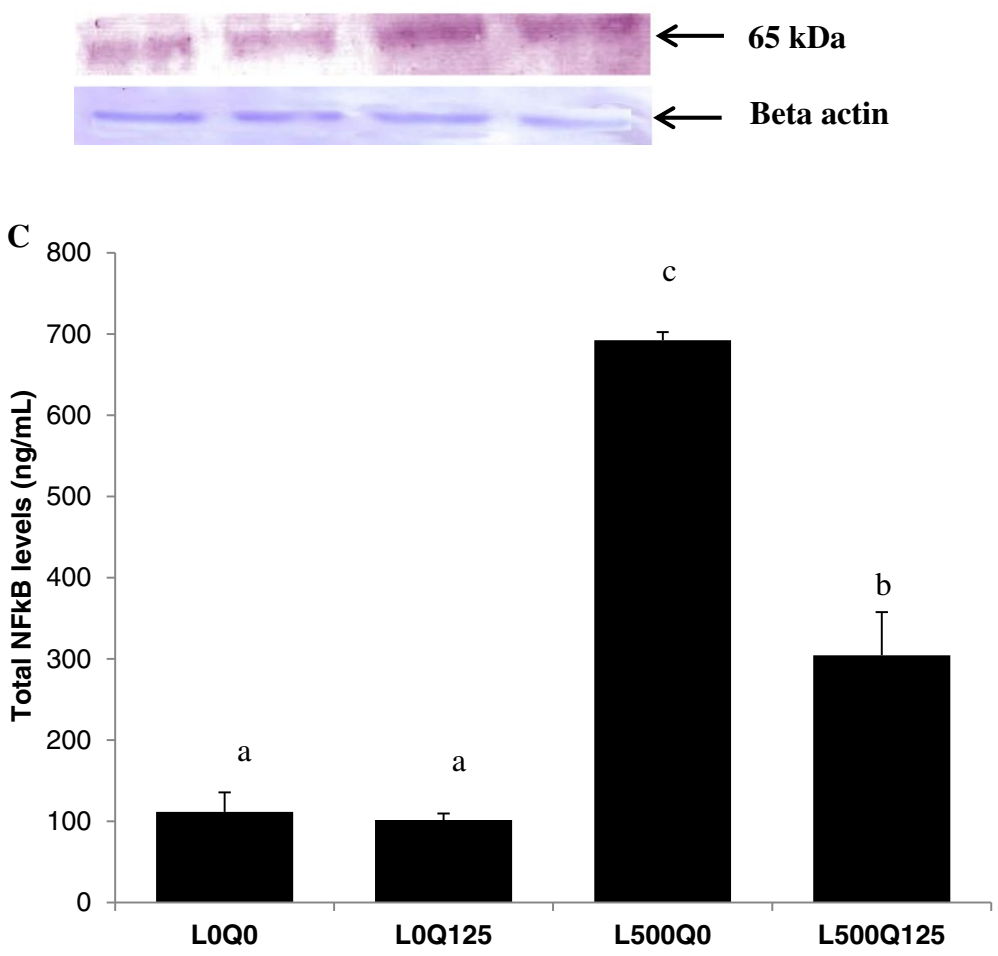

Figure 4 Quercetin inhibits leptin-induced NFKB activation. (A) FITC immunofluorescence labeling showed the signal density was increased after $500 \mathrm{ng} / \mathrm{mL}$ leptin exposure as compared to control. Quercetin addition in leptin-induced HUVECs reduced the density of NFKB. Panel 1 control HUVECs without leptin and quercetin; panel 2 without leptin, but with $125 \mu \mathrm{M}$ quercetin; panel 3 with $500 \mathrm{ng} / \mathrm{mL}$ leptin, but without quercetin; panel 4 with $500 \mathrm{ng} / \mathrm{mL}$ leptin and $125 \mu \mathrm{M}$ quercetin. (B) Western blot analysis of p65 NFKB in HUVECs confirmed the immunofluorescence labeling. LOQ0 control HUVECs without leptin and quercetin; L0Q125 without leptin, with $125 \mu$ M quercetin; L500Q0 with $500 \mathrm{ng} / \mathrm{mL}$ leptin, without quercetin; L500Q125 with $500 \mathrm{ng} / \mathrm{mL}$ leptin and $125 \mu$ M quercetin. (C) ELISA measurement showed a significant increased of NFKB activation in leptin-induced HUVECs when compared to control, and quercetin administration significantly reduced the activated NFKB level. LOQ0 control HUVECs without leptin and quercetin; LOQ125 without leptin, but with $125 \mu \mathrm{M}$ quercetin; L500Q0 with $500 \mathrm{ng} / \mathrm{mL}$ leptin, but without quercetin; L500Q125 with $500 \mathrm{ng} / \mathrm{mL}$ leptin and $125 \mu \mathrm{M}$ quercetin. Means without a common letter differ, $p<0.001$. 
$\left.p=10^{-4}\right)$. Quercetin alone did not activate NFKB (Figure 4C).

\section{Quercetin partially suppressed leptin-induced TNFa secretion}

Secreted TNF $\alpha$ level was markedly increased by $3.2 \mathrm{x}$ in leptin-induced HUVECs as compared to control (22.39 \pm 2.29 vs. $72.50 \pm 7.33 \mathrm{ng} / \mathrm{mL}$, L0Q0 vs. L500Q0, $\left.p=10^{-4}\right)$. TNF $\alpha$ secretion was decreased, albeit partially $(0.8 \mathrm{x})$, after quercetin addition in leptin-induced HUVECs (L500Q125) when compared to leptin-induced HUVECs without quercetin (L0Q125) $(60.38 \pm 1.04$ vs. $72.50 \pm 7.33 \mathrm{ng} / \mathrm{mL}$, L500Q125 vs. L500Q0, $p=0.022$ ). TNF $\alpha$ secretation was also increased when HUVECs were exposed to quercetin alone (Figure 5).

\section{Discussion}

We have demonstrated the presence of the short chain leptin receptor isoform Ob-Ra in HUVECs, confirming previous studies [16,17]. We were able to show that Ob-Ra expression was increased after leptin exposure. Leptin has been reported to differentially modulate the expression of its receptors in both dose- and tissuedependent manner [18]. When treated with high leptin concentration, the level of leptin receptor was increased, reported to be due to changes in receptor number that occur prior to gene expression changes [19], which was expected to happen post translationally [20].

We observed that up-regulated Ob-Ra expression was followed by elevated ERK $1 / 2$ phosphorylation, in line with previous reports that demonstrated ERK1 and ERK2 activation by the short leptin receptor isoform [21], and leptin-stimulated pro-inflammatory cytokine release abrogation by ERK 1/2 MAPK inhibitor U0126
[22]. As shown from our result, the elevated ERK1/2 phosphorylation was followed by increased $\mathrm{NF}_{\kappa} B$ activation and TNFa secretion, which was in agreement with a previous report that indicated leptin has proinflammatory action, involving pro-inflammatory cytokines TNF $\alpha$ through NFKB regulation [22].

Quercetin is one of the most widely distributed flavonoids in fruits, vegetables, tea and wine [23], reported to have anti-inflammatory properties, and might act as health-promoting substances $[24,25]$. In this study, we showed that $125 \mu \mathrm{M}$ quercetin was able to downregulate Ob-Ra expression, reduce ERK1/2 phosphorylation, decrease NFKB activation, and partially suppress TNF $\alpha$ secretion in leptin-induced HUVECs. The antiinflammatory effect of quercetin has been described in various reports, among others were the ability to suppress ERK phosphorylation in $3 \mathrm{~T} 3-\mathrm{L} 1$ adipocytes [26] and NCI-H292 cells [27], inhibit NFKB activation in murine J774 macrophages [28] and bone marrowderived macrophages [29], VAT TNF $\alpha$ production in obese Zucker rats [30], reduce the activation of phosphorylated ERK kinase strongly in LPS-induced RAW 264.7 cells and inhibit NFKB activation through both stabilization of $\mathrm{NF \kappa B} / \mathrm{I \kappa} B$ complex and suppression of proinflammatory cytokines including TNF $\alpha$ [31]. In PBMC, a $50 \%$ reduction of TNF $\alpha$ gene expression was observed after $24 \mathrm{~h}$ exposure to $50 \mu \mathrm{M}$ quercetin [14]. A meta-analysis of long-term placebo-controlled human intervention trials reported that TNF $\alpha$ levels were decreased after flavonoid consumption, but only in a fixed model, and a higher dose or a longer duration intervention were not associated with a greater effect size [32]. Although preliminary, our data suggested that suppression of TNF $\alpha$ secretion by quercetin was associated with

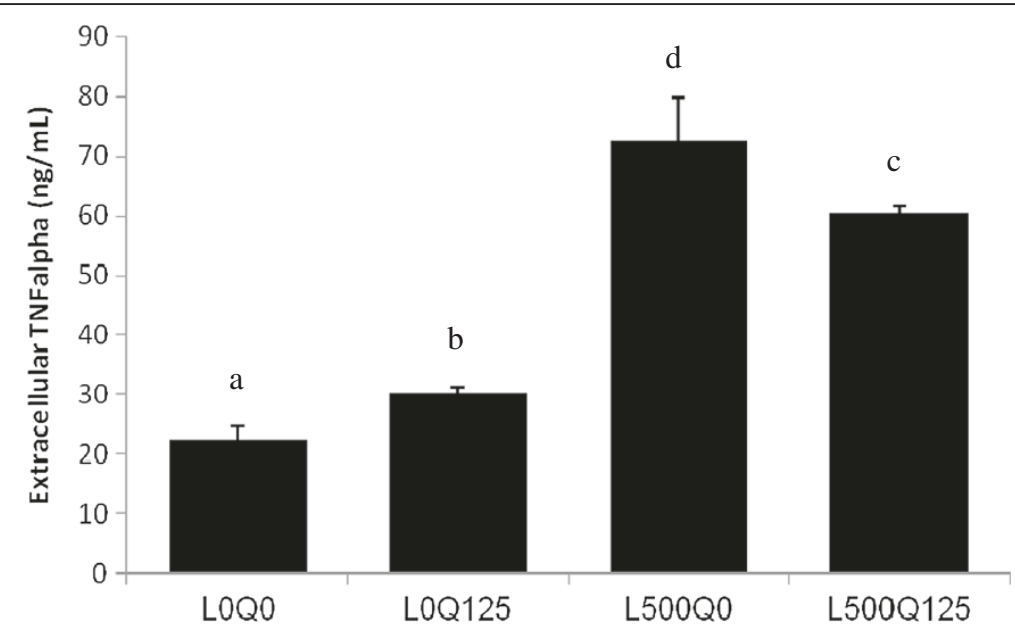

Figure 5 Quercetin partially suppressed leptin-induced TNFa secretion. TNFa secretion was markedly increased in leptin-induced HUVECs as compared to control, and was partially decreased after quercetin addition. LOQ0 control HUVECs without leptin and quercetin; L0Q125 without leptin, but with $125 \mu \mathrm{M}$ quercetin; L500Q0 with $500 \mathrm{ng} / \mathrm{mL}$ leptin, but without quercetin; L500Q125 with 500 ng/mL leptin and $125 \mu \mathrm{M}$ quercetin. Means without a common letter differ, at least $p<0.05$. 
inhibition of $\mathrm{NFKB}_{\mathrm{K}}$ activation, as reported previously [28]. However, our result showed that quercetin suppression of TNFa secretion appeared to be partial, which we believe might be due to the short duration of quercetin exposure period. Although essential, unfortunately we can not perform further confirmation of TNF $\alpha$ suppression by TNF $\alpha$ mRNA assessment, since our samples were not prepared and stored for RNA analysis. This is the limitation of our study, besides that we only apply one quercetin concentration in our study, which might not be the optimum concentration. Further studies, such as measurements of TNF $\alpha$ mRNA and application of NFkB activation inhibitor, are still needed to clarify this discrepancy.

The suppression of inflammation by quercetin may have clinical significance in preventing cardiovascular disease induced by leptin-resistant in obesity. As reported previously, quercetin administration to obese Zucker rats improved dyslipidemia, hypertension, and hyperinsulinemia, all of which are cardiovascular risk factors [30]. A deeper assessements on the molecular mechanisms of quercetin action in suppressing leptin-induced inflammation are needed as high intake of plant-derived food rich in quercetin or the use of supplements of this flavonoid might be protective and could reduce cardiovascular risks. It might also be a promising area for the development of a flavonoid-based neutrapharmaceutical agents for the treatment of chronic inflammatory disease.

\section{Conclusion}

Leptin exposure of HUVECs resulted in up-regulated Ob-Ra expression and elevated ERK1/2 phosphorylation and NFkB activation, and increased TNF-alpha secretion. Despite strong suppression effect of quercetin on the increased Ob-Ra expression, ERK1/2 phosphorylation and NFkB activation, however, TNF $\alpha$ secretion was only partially suppressed. Therefore, further studies are still needed to elucidate the basis of this exception.

\footnotetext{
Abbreviations

HUVECs: Human umbilical vein endothelial cells; TNFa: Tumor necrosis factor alpha; Ob-R: Leptin receptor; MAPK: Mitogen activated protein kinase; ERK1/ 2: Extracellular regulated kinase 1/2; NFkB: Nuclear factor kappa b; L: Leptin; Q: Quercetin; ELISA: Enzyme linked immunosorbent assay; FITC: Fluorescence isothiocyanate; ANOVA: Analysis of variance.
}

\section{Competing interest}

The authors declare that they have no competing interest.

\section{Authors' contributions}

MRI designed the study, performed data analysis, wrote and revised the final manuscript. SK carried out all assays and performed data analysis. RR designed the study, performed data analysis, wrote and revised the final manuscript. SGM provided direction, performed data analysis and revised the final manuscript. All authors have read and approved the final manuscript.

\section{Acknowledgement}

This study was fully funded by Indonesian Danone Institute Foundation (Grant number 10192008-2). The views expressed herein are those of the individual authors, and do not necessarily reflect those of Indonesian Danone Institute Foundation. The authors would like to thank Dr. Budi Siswanto, MD, SpOG who prepared human fetal umbilicals, Ms. Umi Salamah and Mr. Budi Wicaksono for their technical assistance.

\section{Author details}

${ }^{1}$ Department of Physiology, Faculty of Medicine, Brawijaya University, J. Veteran, Malang 65145, East Java, Indonesia. ${ }^{2}$ Eijkman Institute for Molecular Biology, J. Diponegoro 69, Jakarta 10430, Indonesia.

Received: 6 January 2012 Accepted: 24 June 2013

Published: 16 July 2013

\section{References}

1. Badan Penelitian dan Pengembangan Kesehatan, Departemen Kesehatan Republik Indonesia: Laporan hasil riset kesehatan dasar (RISKESDAS) nasional 2007. Jakarta; 2008.

2. de Ferranti S, Mozaffarian D: The perfect storm, adipocyte dysfunction, and metabolic consequences. Clin Chem 2008, 54:945-955.

3. Friedman JM: Leptin at 14 years of age: an ongoing story. Am J Clin Nutr 2009, 89(suppl):973S-979S.

4. Lau DCW, Dhillon B, Yan H, Szmitko PE, Verma S: Adipokines: molecular links between obesity and atherosclerosis. Am J Physiol Heart Circ Physiol 2005, 288:H2031-H2041.

5. Knudson JD, Dincer UD, Zhang C, Swafford AN Jr, Khoshida R, Picchi A, Focardi M, Dick GM, Tune JD: Leptin Receptors are expressed in coronary arteries, and hyperleptinemia causes significant coronary endothelial dysfunction. Am J Physiol 2005, 289:H48-H56.

6. Cao Y: Angiogenesis modulates adipogenesis and obesity. J Clin Invest 2000, 117:2362-2368.

7. Wang Z, Nakayama T: Inflammation, a link between obesity and cardiovascular disease. Mediator Inflamm 2010, 2010:535918.

8. Mehta S, Farmer JA: Obesity and inflammation: a new look at an old problem. Curr Atheroscler Rep 2007, 9:134-138.

9. Libby P: Inflammation in atherosclerosis. Nature 2002, 420:868-874

10. Tedgui A, Mallat Z: Cytokine in atherosclerosis: pathogenic and regulatory pathways. Physio Rev 2006, 86:515-581.

11. Sonnenberg GE, Krakower GR, Kissebah AH: A novel pathway to the manifestations of metabolic syndrome. Obes Res 2004, 12:180-186.

12. Indra MR, Satuman: Increased monocyte chemoatractant protein-1 (MCP-1) level in Human umbillical cein endothelial cell (HUVEC) culture induced by human recombinant leptin. J Kedokteran Brawijaya 2007, 3:20-26.

13. Bischoff SC: Quercetin: potentials in the prevention and therapy of disease. Curr Opin Clin Nutr Metab Care 2008, 11:733-740.

14. Nair MP, Mahajan S, Reynolds JL, Aalinkeel R, Nair H, Schwartz SA, Kandaswarni C: The flavonoid quercetin inhibits proinflamasi cytokine (TNFa) gene expression in normal peripheral blood mononuclear cells in via modulation of the NF- KB system. Clin Vaccine Immunol 2006, 13:319-328

15. Quehenberger $P$, Exner $M$, Sunder-Plassmann R, Ruzicka K, Bieglmayer $C$, Endler G, Muellner C, Speiser W, Wagner O: Leptin induces endothelin-1 in endothelial cells in vitro. Circ Res 2002, 90:711-718.

16. Bouloumie A, Drexler HCA, Lafontan M, Busse R: Leptin, the product of Ob gene, promotes angiogenesis. Circ Res 1998, 83:1059-1066.

17. Akerman F, Lei ZM, Rao CV: Human umbilical cord and fetal membranes co-express leptin and its receptor genes. Gynecol Endocrinol 2002, 16:299-306.

18. Di Yorio MP, Bilbao MG, Pustovrh MC, Prestifilippo JP, Faletti AG: Leptin modulates the expression of its receptors in the hypothalamic-pituitary-ovarian axis in a differential way. J Endocrinol 2008, 198:355-366.

19. Mitchell SE, Nogueiras R, Morris A, Tovar S, Grant C, Cruickshank M, Rayner DV, Dieguez C, Williams LM: Leptin receptor gene expression and number in the brain are regulated by leptin level and nutritional status. J Physiol 2009, 587:3573-3585.

20. Frühbeck $\mathrm{G}$ : Intracellular signalling pathways activated by leptin. Biochem J 2006, 393:7-20.

21. Bjørbaek C, Uotani S, da Silva B, Flier JS: Divergent signaling capacities of the long and short isoforms of the leptin receptor. J Biol Chem 1997, 272:32686-32695.

22. Lappas M, Permezel M, Rice GE: Leptin and adiponectin stimulate the release of proinflammatory cytokine and prostaglandins from human 
placenta and maternal adipose tissue via nuclear factor-кB, peroxisomal proliferator-activated receptor- $\gamma$ and extracellularly regulated kinase $1 / 2$. Endocrinology 2005, 146:3334-3342.

23. Perez-Vizcaino F, Duarte J: Flavonols and cardiovascular disease. Mol Aspects Med 2010, 31:478-494.

24. Ruiz PA, Braune A, Holzlwimmer G, Quintanilla-Fend L, Haller D: Quercetin inhibits TNF-induced NF- $\mathrm{KB}$ transcription factor recruitment to proinflammatory gene promoters in murine intestinal epithelial cells. J Nutr 2007, 137:1208-1215.

25. Middleton E Jr, Kandaswami C, Theoharides TC: The effects of plant flavonoids on mammalian cells: implications for inflammation, heart disease, and cancer. Pharmacol Rev 2000, 52:673-751.

26. Ahn J, Lee H, Kim S, Park J, Ha T: The anti-obesity effect of quercetin is mediated by the AMPK and MAPK signaling pathways. Biochem Biophys Res Commun 2008, 373:545-549.

27. Kwon SH, Nam Jl, Kim SH, Kim JH, Yoon JH, Kim KS: Kaempferol and quercetin, essential ingredients in Ginkgo biloba extract, inhibit interleukin-1 beta-induced MUC5AC gene expression in human airway epithelial cells. Phytother Res 2009, 23:1708-1712.

28. Comalada M, Camuesco D, Sierra S, Ballester I, Xaus J, Galvez J, Zarzuelo A: In vivo quercitrin anti-inflammatory effect involves release of quercetin, which inhibits inflammation through down-regulation of the NF-kappaB pathway. Eur J Immunol 2005, 35:584-592.

29. Hämäläinen $M$, Nieminen $R$, Vuorela $P$, Heinonen $M$, Moilanen E: Anti-inflammatory effects of flavonoids: genistein, kaempferol, quercetin, and daidzein inhibit STAT-1 and NF-kappaB activations, whereas flavone, isorhamnetin, naringenin, and pelargonidin inhibit only NF-kappaB activation along with their inhibitory effect on iNOS expression and NO production in activated macrophages. Mediators Inflamm 2007, 2007:45673.

30. Rivera L, Morón R, Sánchez M, Zarzuelo A, Galisteo M: Quercetin ameliorates metabolic syndrome and improves the inflammatory status in obese Zucker rats. Obesity (Silver Spring) 2008, 16:2081-2087.

31. Cho SY, Park SJ, Kwon MJ, Jeong TS, Bok SH, Choi WY, Jeong WI, Ryu SY, Do SH, Lee CS, Song JC, Jeong KS: Quercetin suppresses proinflammatory cytokines production through MAP kinases andNF-kappaB pathway in lipopolysaccharide-stimulated macrophage. Mol Cell Biochem 2003, 243:153-160.

32. Peluso I, Raguzzini A, Serafini M: Effect of flavonoids on circulating levels of TNF- $a$ and IL- 6 in humans: a systematic review and meta-analysis. Mol Nutr Food Res 2013. doi:10.1002/mnfr.201200721 [Epub ahead of print].

\section{doi:10.1186/1756-0500-6-275}

Cite this article as: Indra et al:: Quercetin suppresses inflammation by reducing ERK1/2 phosphorylation and NF kappa B activation in Leptininduced Human Umbilical Vein Endothelial Cells (HUVECs). BMC Research Notes 2013 6:275.

\section{Submit your next manuscript to BioMed Central and take full advantage of:}

- Convenient online submission

- Thorough peer review

- No space constraints or color figure charges

- Immediate publication on acceptance

- Inclusion in PubMed, CAS, Scopus and Google Scholar

- Research which is freely available for redistribution 